DOI: https://doi.org/10.31392/NPU-nc.series9.2018.17.05

UDC: 81 '384

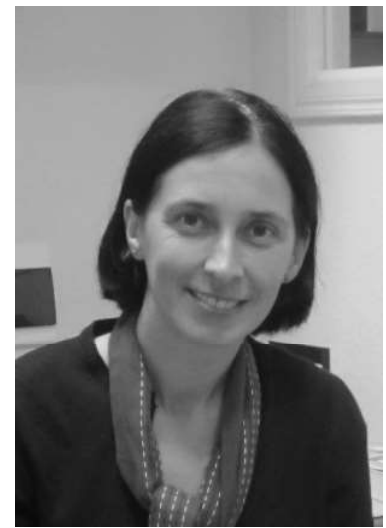

National Pedagogical Dragomanov University, Kyiv, Ukraine

\title{
THEOCONCEPT STRUCTURE RECONSTRUCTION AS MULTI-DIMENSIONAL MATRIX FORMATION
}

\section{Bibliographic Description:}

Izyumtseva, G. V. (2018). Theoconcept Structure Reconstruction as MultiDimensional Matrix Formation. Scientific Journal of National Pedagogical Dragomanov University. Series 9. Current Trends in Language Development. K. 17. 57-67. DOI: https://doi.org/10.31392/NPU-nc.series9.2018.17.05

Abstract

The article addresses the problem of structure reconstruction of the theoconcept as a sensecreating basic component of religious picture of the world. The theoconcept is interpreted as a multi-dimensional formation which embodies experience of a man (people), both physical and spiritual; and is at the same time typified by a historically conditioned worldview constituent. The rational for employing the diachronicsynchronic approach to account for the concept structure is provided. Major emphasis is placed on the study of theoconcepts against concepts of other types and their modes, particularly, as abstract ontological-intuitive mental entities.

Reconstruction of seven levels of the theoconcept REPENTANCE structure is conducted; it bears evidence that this formation is of cognitive-matrix format. It is found that the kernel content of the theoconcept REPENTANCE has been developed on the base of a meaning "turn", which, according to the Biblical context of conceptualization, reconstructs the essence of repentance (level one). The kernel-centered (circumnuclear) area is formed by such meanings, as "confession", "sacrament", "penance", "reconciliation", "testament", "reunion", with basics of Orthodox doctrine as cognitive contexts (level two). Ethnic coloring of the concept meaning is revealed through such spiritual sense of the theoconcept REPENTANCE, as "congregational confession" (level three). The image of repentance as "the second baptism" emerges in the context of Christian symbolic meanings (level four). The shade of meaning "to turn away" ("military command") has been developed in a process of its folk-etymological conceptualization, and constitutes the periphery of the concept (level fife). In a context of monastic movement in Ukrainian lands, and life of monks (level six) shades of meanings "atonement", "asceticism", "hermitage", "anchorite" are being actualized. The last level (distant area) of senses embraces the individual-specific shades of senses, personal shades of senses of the concept under consideration, present in idiolects of the faithful.

Finally, the results indicate that reconstructed sense levels are the cognitive contexts to interpret the kernel meaning of the theoconcept REPENTANCE. They bring into focus (highlight) its other senses, which interplay and produce its conceptual multi-aspectedness and multi-dimensionality that is nothing but matrix.

Keywords: theolinguistics, theoconcept REPENTANCE, cognitive matrix, field model of a theoconcept. 


\section{Introduction.}

In the context of ongoing shift toward ontological and epistemological perspective within contemporary linguistics, as V. I. Postovalova points out, scholars are returning to the world of being by selecting to study such units that are capable of providing utmost insights into the spiritual world of a man. The choice typically turns next to the concepts as such and religious concepts in particular; the latter have been studied lately within a framework of theoconceptology (Postovalova 2014a: 128). V. A. Stepanenko accurately and fairly expresses the value of such investigation by saying that "if linguistics ignores the spiritual knowledge, it, as any other science about a man, risks remaining shallow" (Stepanenko 2011: 13).

In a present-day linguistics, even though some linguoconceptoplogical studies that tend to so-called "conceptomania" (A. M. Prykhodko) begin to arouse criticism, promising prospects within this sphere are being offered by theolinguistics (O. O. Cherkhava, O. Hadomskyi, D. Krystal, N. Mechkovska, Y.-P. van Noppen, and others) - a new integrated discipline that crosses disciplinary boundaries and aims at examining the interaction between language and religion (Gadomskiy 2004: 166). In Y. P. Senokosov's opinion, "language is our only reality that comprises "physics" and "meta-physics"; thus, it is capable of providing an access to the "Absolute"; and therefore, an access to new knowledge" (cited in: Mamardashvili 1997: 301).

According to I. V. Buhaieva, theolinguistic research centers around religious communication and religious picture of the world (Bugayeva 2014: 294), which is constituted by entirety of religious concepts (theoconcepts) and demonstrates its significance for the spiritual life of an individual (Postovalova 2014a: 129) by reflecting in language the religious worldview (Bugayeva 2014: 294-295). In reconstruction of the religious picture modelling mechanism based on interrelation of religious concepts rests that promising aspect of linguoconceptological development that will make it possible to reveal in what way such research is actually essential; and above all, in due course, it will provide answer to the questions how a concept acquires its mental characteristics, and where the origins of its mentalization lie.

\section{Aim.}

The aim of the article is to reconstruct the structure of a theoconcept as a sensecreating basic element of religious picture of the world.

\section{Processes of Acquiring Consciousness Mental Structure Status by a Concept.}

To rationalize the theoconcept as one of the concept types, we ought to provide in a nutshell the linguoconceptological provisions which will ensure the optimal definition of this structure of human consciousness.

Conceived within the medieval mind (P. Abeliard (Neretina 2010: 306)) introduced to linguistics by scholar S. A. Askoldov, with the advent of cognitive linguistics the term "concept" has eventually turned into a stem term (Kratkiy slovar 1996: 90-93; Stepanov 1997: 40-76).

Ye.S. Kubryakova considers the concept as a fundamental unit of human consciousness; a constituent of "collective subconscious"; the"operational meaningful unit of memory; the unit of our consciousness mental and psychic resources, which reflects the content of experience and knowledge in a form of some "quanta" of knowledge; is partially verbalized by language means, embracing along with it a portion of information in a nonverbal form" (Kratkiy slovar 1996: 90). Yu. V. Stepanov holds the same opinion speaking about a concept as the "energetic bunch of culture, mental picture of something that not always can be verbalized; however, can be seen, heard, sensed, felt, recognized, perceived, and recalled [...]" (Stepanov 1997: 40, 68). 
The development of concepts, as M. M. Boldyrev points out in his research, occurs gradually during a person's lifespan. In a course of activities through the acts of cognition (perceptual and rational), an individual creates general notions, which later are integrated in a system of knowledge about the world. Such system is constituted by concepts of different level of complexity and degree of abstractedness; varying in means of formation (Boldyrev 2001: 23). Resting on such M. M. Boldyrev's observation as well as the observation of other scholars, A. Yu. Sternin's in particular, in a process of acquisition by a concept of its status the following factors are involved: 1) perceptual experience; 2) substantive work; 3) cognitive toying with already existing concepts; 4) speech acts; 5) learning new meanings of lingual units (learning new lingual units fixed by dictionaries, reference books etc.) (Popova, Sternin 2001, 2007; Boldyrev 2001).

At the same time, the type of data collected by psychologist N. I. Zhinkin in an area of speech production has thrown more light on the process of the concept formation, and significantly enriched the comprehension of the concept essence (Zhinkin 1998). N. I. Zhinkin came to conclusion that thinking process is realized through some subjective, not akin to the verbal one, code units (resulting from internalization of objective external actions). It is the "code of subject and scheme", which is also called the Universal SubjectScheme Code (USC). The USC are neurophysiologic entities, perception images, schemes, representations, emotional imprints of reality which codify elements of knowledge (concepts) integrating and differentiating them at the level of consciousness according to different principles. The USC is universal (all people have it), substantive (its signs signify predominantly substantive images), and at the same time subjective (unique for each speaker, as it is created as a reflection of his one of a kind, individual, sensual life experience) (Sternin 2015: 15).

Thus, in a process of evolution (acquiring its status), concepts start as sensual images. The USC entities codify them at the level of consciousness. The USC that is characterized by individual subject-image nature, constitutes the brightest visual stable kernel part of a concept, which subsequently gets wrapped up in layers of knowledge, namely: empirical (attained through experience), encyclopaedic (the source of which is trust in authority) and doxastic (with thoughts, judgments, and beliefs as the source). In the opinion of L. O. Cherneiko, the former is naive knowledge; it constitutes the content of folk consciousness of an individual (Cherneyko 2010).

\section{Evolution of Concept and its Structure Modelling.}

The delineated above approach to concept evolution brings us close to the issue of formation of a concept structure as a mental process described by researchers according to the kernel-periphery principle; here with, the core (kernel) was considered to be the most concrete sensual-visual image of a concept, its USC - a prototypical formation that can be of nationwide, collective as well as of individual character; while basic layers that are varying according to degree of abstractedness and developing sequence of layers - core-centered (circumnuclear); the developing sequence of layers depends on subjective and individual conditions of a concept formation; at the same time the periphery of a concept is understood as its interpretative field, which incorporates estimative characteristic of a concept core as viewed through the lens of national, collective and individual consciousness (Popova, Sternin 2001).

The field structure (that is such structure) of a concept is favoured by majority of scholars (Yu. M. Karasyk, M. V. Nikitin, A. M. Prykhodko et al.), albeit the number and content of layers constituting the concept structure may vary (cited in: Selivanova 2008: 417) Among the alternative models of a concept structure, the diffusive model of a concept 
structure is put forward. Unlike the field structure, it is characterized by diffusive character, that is, the conceptual futures are of "overflowing" character (Popova, Sternin 2007: 302).

In our opinion, these models fail to account for origins of a concept kernel organization. However, convincing account is put forward by A. V. Korolyova who has thoroughly analysed available approaches to a concept structure, and has identified the genetic foundation of a concept, that is, in the opinion of the scholar, "etymology of a concept name as well as its representatives, their implicit form that allows a researcher to trace how the concept meaning has changed over time, and consequently, to establish semantic regularities revealing themselves in a process of categorization and conceptualization of a segment of reality named by this particular concept" (Korolyova 2011: 57). On this premise, the concept structure ought to be viewed within the framework of the diachronic-synchronic approach to analysis. The structural elements ought to be established "via correlation between original (primary) information of its names (historical and etymological) and such that is represented within a concept at the present stage (actual information)" (Korolyova 2011: 54). In line with the approach elaborated by A. V. Korolyova is the position of L. O. Cherneiko that is accurately expressed in the thought that "the name of a concept embraces the lingual transformation of all kinds of knowledge about the phenomenon it stands for" (Cherneyko 2010: 203-206).

\section{Interrelation of a Concept Structure with Two Types of Concepts: Abstract and} Concrete.

It becomes evident that the notion of a concept structure and the concept type identification are closely connected, and should be discussed together. Taking into account the fact that theoconcepts belong to the domain of sacred, to differentiate between concrete and abstract concepts is essential. Unlike the abstract concepts, the concrete concepts, due to undergirding sensual foundation, are easily described and illustrated. Moreover, abstract concepts refer to realities which often are not easy to imagine or explain. Researchers state that abstract concepts "defuse" and are "not completely unveiled" (S. O. AskoldovAleksieiev). In O. P. Babushkin's opinion, the distinctiveness of abstract concepts consists in their "individuality, modal-evaluative character; they are determined by moral standards and traditions of socium" (Babushkin 1977: 33). They come to the fore as entities "metaphysical" (S. H. Vorkachev), "ideal" (L. O. Cherneyko), requiring deeper explanation, and better "anchorage in sign" (Nikitin 2003) (cited in: Belyutin 2005: 21).

Among other concept modes, researcher M. V. Nikitin lists, in the first place, the mode of conceptual systematization of the world and its entities (Nikitin 2003: 54), inasmuch as their relations and inter-relations with other concepts underlie classes and categories reflecting deep structure of the world.

According to J. Bruner, the category is a set of rules employed to classify the objects (Bruner 1977). G. Lakoff views categories as forms and stable organizing principles of thinking that reproduce features and relations of being and cognizing in the most concentrated way. "To change the very concept of a category is to change not only our concept of the mind, but also our understanding of the world" (Lakoff 1990: 9). M. V. Nikitin points out that ontological objects reveal unlimited number of attributes; therefore, such objects can be classified according to different attributes a number of times. However, as the researcher continues, the attributes, used as a basis for categorization, vary in the degree of informative value; that is, they allow forecasting more or less implicitly connected features. This explains why classifications are, albeit not rigidly, divided into primary taxonomic and secondary non-taxonomic classifications. Prime taxonomic classification is characterized by maximal informativeness and forecasting capability, because it reflects the structure of the world to the maximum, ranging the properties in the 
world entities at different levels of generalization (Nikitin 2003: 684), and, as empirical anthropological studying prove, it is genetically predetermined (Artran 1998: 203; Lopez, Artran, Coley \& Medin 1997).

In her empirical studies, Eleonor Rosch has proved the existence of three levels of categorization, namely: the superordinate (the most abstract upper level); the basic and subordinate (more concrete lower level) levels (Croft \& Cruse 2004: 82-87; Rosch 1978: 28-35). The superordinate level which is, as we have already mentioned, characterized by high abstractedness and manifest high degree of generality, reveals itself in such categories, as, for instance, "natural objects", "persons", "artefacts" etc. (Croft \& Cruse 2004: 85).

Let us dwell on the intuitive ontological categories that are similar to main taxonomic categories but not identical to them. The notion "intuitive ontology" was introduced by P. Boyer, Professor of Washington University in St. Louis (the USA) whose works became revolutionary in the domain of cognitive religion. In his investigation, P. Boyer rests on the findings in an area of natural categorization (B. Berlin, F. Keil, Yu. Khann, E. Rosh). The model of "ontological knowledge" presented in a form of "ontological tree" (F. Keil) consisting of natural classes reflects how people intuitively categorize the world around (Keil 1979). It should be added that within cognitive science intuitive is understood in sense of naïve, folk, "that it is not a product of deliberate reflection on what the world is like" (Barrett 2008: 310).

Unlike main taxonomic categories, the intuitive ontological categories are domains of intuitive knowledge that exist in a form of tacit knowledge which guides people in a process of perception and conceptualization of reality (Fodor 1968; Rosch, 1973; Spelke, 1991). The intuitive ontological categories evolve throughout life, and all together constitute "intuitive ontology" of a person (Boyer, Barrett 2015). The intuitive ontological categories reveal themselves through so-called theories about the world: "naïvelfolk physics" (Lipman \& Bogen 1923) (intuitive knowledge enabling people to act adequately in physical world); "naïve/folk biology" (connected with a process of conceptualization and classification of objects of organic world) (Artran 1999), "naïvelfolk psychology" ("theory of mind") knowledge that enable people to represent other people's psychic states, attribute motivations and intentions to oneself, and to others, and to interpret own actions and behaviour of others in terms of desires, convictions, expectations etc. (Churchland, 1989; Whiten 1991).

Thus, the development of categories is connected with origin of concepts, their existence and grouping in stable cognitive formations, one of which is theoconcept, or religious concept. Review of modes of conceptual systematization of the world and its entities has revealed the existence of main ontological (taxonomic) categories and intuitive ontological categories. As P. Boyer points out, albeit the criteria of intuitive ontology remain fuzzy, as the research outcome proves, they are integrated and present within cognition of an individual (Boyer 1996).

\section{The Structure of a Theoconcept against the Structure of other Abstract Concepts.}

The theoconcept as an abstract ontological-intuitive mental entity requires determination of its distinctive features. In her justifications of peculiarities of religious concepts, V. I. Postovalova rests on general for linguistics definition of concepts, namely that concepts are the "minimal quantum of knowledge incorporating in a condensed form the most significant to humankind ideas about being in general and the being of a man in particular" (Postovalova 2014a: 130). The scholar points out that within the religious picture of the world "in the light of theoanthropologic prospect, religious concepts present themselves as spiritual (ontological) reality" (Postovalova 2014a: 132).

In addition, the valid, in this context, seems a thought that religious concepts do not constitute an autonomous type; and thus, can be studied against other concepts (Boyer 2001); 
however, on the understanding that these entities (religious concepts) most certainly fix peculiar human experience and emotions (Baumard \& Boyer 2013); are characterized by special content, and stability: better resist time and other concepts (Boyer 2000: 196); are attention grabbing, easily remembered and recollected, that is why are more likely to be transmitted and spread (Barrett 2008; Boyer \& Ramble, 2001; Johnson, Kelly \& Bishop 2010; Upal, Owsianiecki, Slone 2007; and others).

In the light of the aforesaid, it becomes clear that a theoconcept belongs to the sacred sphere of religious picture of the world; moreover, studying its structure as such is returning of conceptology to its roots: it in its time originated in a form of peculiar intellectual and spiritual endeavour to conceive and comment the texts of the Holy Scriptures. (Implementation of P. Abeliard's principle "perceive, to believe"). "Conceiving own concept, own opinion, a medieval person became an author of his own Word or Book, expressed through commentaries" (Neretina 1994: 142).

"Endeavours of theoconcetology focus at reconstruction of the world-view aspect of the religious concepts content, complementing and correcting the structure of a concept, discovered using the methods for analysis of cultural semantics units. V. I. Postovalova underlines that the spiritual and world-view stage in interpretation of religious concepts marks the limit of their kataphatic cognizing; at the same time it brings to light apophatic dimension that is beyond human understanding" (Postovalova 2014a).

The idea of spiritual essence of concepts are running through the works of the first conceptologist - P. Abeliard, who in his time defined a concept as "a spiritual act realized via speech" (Neretina 2010: 306). V. A. Stepanenko in her analysis of the concept "Душа. Seele. Soul", justifying its ontological aspect, among other ontological conceptual features singles out such feature as "God-breathedness" (Stepanenko 2006: 33-34). It worth noting that "God-breathedness" is a Biblical term: "All Scripture is God-breathed" (2 Tymothy 3: 15-17). It is a principal concept undergirding the Christian doctrine on divine origin of the Bible. According to V. A. Stepanenko, it is the concept feature "God-breathedness" that embraces the mystical knowledge essential for ontological understanding of a given concept. However, as the researcher explains, presence of such knowledge itself is not a guaranty of its accessibility as well as comprehension of a concept, because from ontological standpoint, exhaustive comprehension of a concept belongs to Proper Name / God / Absolute (Stepanenko 2006: 34).

Generalizing from ideas and research outcome of such scholars, as F. Bethen, F. Bystrov, S. M. Zarin, P. O. Florenskyi, V. I. Postovalova claims that the only way to unveil the spiritual essence of spiritual concepts if from inside of a particular denominational world-view, from inside of "spiritual cosmos" of a given belief system. Thus, for Christians, it is, according to P. O. Florenskyi, the idea of salvation in terms of soteriological category (Florenskiy 1999: 468). In line with this we will add that salvation is a result of conversion, the "gift of God" (Ephesians 2, 8-9). Saint Augustine had experienced and described it as an act of almighty power of grace. As an act of enlightment of the heart and mind; however, at the same time, the act of power that it was hard to resist (Blazhennyy Avgustin 1996). Saint Augustine's life, a number of examples from the Holy Scriptures (Moses (The Pentateuch), Paul (Saul) and his conversion on his way to Damascus (Acts 9:4,5); conversion and baptizing of eunuch (Acts 8:26-39) and many others serve as an example of above stated.

Thus, exhausting comprehension of the spiritual constituent of a theoconcept structure - its kernel and other strata - layers seems to be a vocation of chosen ones, since it demands not mere detailed scientific analysis but also sanctification (Cherkhava 2017). Although, sometimes even spiritual experience fails to disclose what must be concealed from a man. The Athon dispute over the power of God's name (whether the name of God is God Himself 
or the name of God is a sacred verbal symbol) convincingly demonstrates this thought (Postovalova 2014b). The Athon dispute problem remains unsolved, and actually cannot be solved. A man is not capable of perceive and comprehend the world in its entirety.

V. I. Postovalova puts forward such structure of a theoconcept (religious concept) as a multi-dimensional formation, according to O. O. Cherkhava, of a matrix-like format, that has seven levels or spheres of conceptual content: 1) invariant; 2) basic; 3) ethnic variants of confessional spiritual senses; 4) shades of senses filtered through a prism of symbols inherent in a particular spiritual culture (nationwide or confessional); 5) shades of senses that are entailed by reflexion on a lingual form of a concept and folk-etymological sense; 6) various shades of a concept sense that are entailed by interpretation and living through (experiencing) the concept by different communities at various times (general church life, monasterial life, etc.); 7) individual-specific senses, personal shades of senses incorporated in idiolects of separate representatives of religious community (Postovalova 2014a: 139143).

\section{The Theoconcept REPENTANCE Structure Reconstruction.}

Let us reconstruct the delineated above levels within the structure of a concept REPENTANCE (Каяття) - the one of paramount importance for Orthodox-Christian world view.

According to the first - invariant level, this embraces supranational, supracultural, confessional kernel content that is common for joint consciousness as such. Within Christianity, concept REPENTANCE is interpreted in a general way as "turn" (Mathew 18:3; Jeremiah 18:11): a man is expected to turn away from sin and turn to God, confess sin and sincerely seek forgiveness.

The second and that is a basic level of this concept meaning reflects the world-view senses, which are formed within the framework of particular denomination division. At this level the kernel meanings are enriched by senses like "confession", "sacrament", "penance", "reconciliation", "testament", the "second baptism", "reunion". The Orthodox Church teaches that repentance is considered to be one of seven Sacraments of Christian Church the Sacrament of Reconciliation. Since any man by sinning rebels against God, and consequently, his sin separates him from God and Church (Luke 11:23), he needs reconciliation. The only way to be reconciled with God and to return to Him and the bosom of His Church is through true repentance. That is why the pastor's absolvent words in the Sacrament of Reconciliation service are preceded by a prayer about reconciliation and reunion of the one, who is partaking in the Sacrament, with the Holy Church through Jesus Christ the Lord. Repentance is also the testament between a man and God - sincere promise of a sinner to correct the ways of life (Ilarion (Alfeyev), iyerom. 1996: 162, 163).

The third content level of the concept under consideration is represented by spiritual senses inherent in ethnical variants of denominational subdivisions. Unlike the Greek Church, for instance, the Ukrainian Orthodox Church has a practice (in time of need) of "mutual confession". It may take place when the church congregation is too big for a priest to pronounce the forgiveness over each member of congregation individually. In such cases the priest reads audibly the list of faults to confess, and congregation (each person individually examining the state of his heart) responses "Repenting", "I have sinned", or keeps silence (Ilarion (Alfeyev), iyerom. 1996: 164).

The fourth content level of the concept reveals the symbolic shades of senses inherent in a particular spiritual culture (nationwide or denominational). In Christianity baptism is one of acknowledged symbols. On the one hand, it is the Sacrament; on the other hand, - a public testimony of repentance and public "pledge of a clear conscience toward God" (1 Peter $3: 21)$. Importantly, water is visual symbol of the inner purification of the" soul baptized; also 
the anointing by the priest symbolizes the graceful touch of the Holy Spirit. Thus, repentance is understood as the second baptism stressing its purifying and renovating power (Ilarion (Alfeyev), iyerom. 1996: 162).

At the fifth level, the shades of senses, which are entailed by reflexion on a lingual form of a concept, senses that incorporate its folk and etymological perception have been unveiled. One of such shades of the concept REPENTANCE is a meaning to turn away; "repent" was a military command which meant to make an "about face" (to turn around 180 degrees). Such meaning precisely explains and demonstrates the essence of the act of repentance as turning away from sin not in words but in deeds (Smalley 2016: 80).

The sixth level, as we have already delineated earlier, reveals various shades of a concept sense that are entailed by interpretation and living through (experiencing) the concept by different communities at various times (general church life, monasterial life etc.). Thus, the sense of a concept REPENTANCE is enriched and expanded through such notions, as "atonement", "asceticism", "hermitage", and "anchorite", that are tightly connected with a monasterial movement in Ukrainian lands; with the lifestyle of monks who had deliberately withdrawn from secular world, lived a solitary life dedicated to prayer and confession, according to rigid principles of asceticism.

The last seventh level of senses - the conceptual features incorporating individualspecific shades of senses, personal shades of senses reflected in idiolects of separate representatives of religious community.

\section{Conclusions.}

In conclusion, we will point out that theolinguistic approach to reconstruction of concepts allows disclosing cognitive mechanisms of their formation as mental structures of consciousness and sensecreating components of the picture of the world. On the one hand, the theoconcept is a basic component of religious picture of the world; on the other hand, it is a multidimensional formation which embodies experience of a man (people), both physical and spiritual. This gives reason to believe that it is the diachronic-synchronic vector that is essential for such type concepts structure reconstruction. With its help, it becomes possible to establish not only a field arrangement of the concept structure but also to restore the origins of its mentalization, i.e. primary conceptual features of a kernel area formation.

Theoconcepts are abstract ontological-intuitive mental entities, the structure of which comprises seven levels. The theoconcept REPENTANCE is a mental formation of cognitivematrix format which also comprises seven spheres. In the article the cognitive matrix of a theoconcept is explicated as a system of various spheres (seven in our case) of its organization within religious picture of the world that allows presenting all necessary knowledge about it as a mental formation.

It is found that the kernel content of the theoconcept REPENTANCE has been developed on the base of a meaning "turn", which, according to the Biblical context of conceptualization, reconstructs the essence of repentance (level one). The kernel-centered (circumnuclear) area is formed by such meanings, as "confession", "sacrament", "penance", "reconciliation", "testament", "reunion", with basics of Orthodox doctrine as cognitive contexts (level two). Ethnic colouring of the concept meaning is revealed through such spiritual sense of the theoconcept REPENTANCE, as "congregational confession" (level three). The image of repentance as "the second baptism" emerges in the context of Christian symbolic meanings (level four). The shade of meaning "to turn away" ("military command") has been developed in a process of its folk-etymological conceptualization, and constitutes the periphery of the concept (level fife). In a context of monastic movement in Ukrainian lands, and life of monks (level six) shades of meanings "atonement", "asceticism", "hermitage", and "anchorite" are being actualized. The last level (distant area) of senses 
embraces the individual-specific shades of senses, personal shades of senses of the concept under consideration, present in idiolects of the faithful.

Finally, the results indicate that reconstructed sense levels are the cognitive contexts to interpret the kernel meaning of the theoconcept REPENTANCE. They bring into focus its other senses, which interplay and produce its conceptual multi-aspectedness and multidimensionality that is nothing but matrix.

\section{References}

Atran, S. (1999). Folkbiology. The MIT Encyclopedia of the Cognitive Sciences. eds R. Wilson, Fr. Keil. MIT Press. 316-317.

Babushkin, A. P. (1997). Tipy kontseptov v leksiko-frazeologicheskoy semantike yazyka, ikh lichnostnaya $i$ natsional'naya spetsifika [Types of concepts in the lexico-phraseological semantics of the language, their personal and national specificity]: avtoref. dis. ... d-ra filol. nauk: 10.02.19. Voronezh. 41.

Barrett, J. L. (2008). Coding and quantifying counterintuitiveness in religious concepts: Theoretical and methodological reflections. Method \& Theory in the Study of Religion. 20. P. 308-338.

Barrett, J. L., Burdett E. R., Porter T. (2009). Counterintuitiveness in folktales: Finding the cognitive optimum. Journal of Cognition and Culture. 9. 271-287.

Baumard, N, Boyer, P. (2013). Explaining moral religions. Trends in Cognitive in Science. 17(6). P. 272280. Retrieved from http://dx.doi.org/10.1016/j.tics.2013.04.003.

Belyutin, R. V. (2003). Metaforicheskaya reprezentatsiya abstraktnykh kontseptov GEDANKE I WORT: kognitivnyy aspekt (na materiale nemetskogo yazyka) [Mataphorical representation of abstract concepts GEDANKE AND WORT: cognitive aspect (based on the German language material)]. Smolensk: SGU. 216.

Blazhennyy Avgustin (1996). Enkhiridion ili o vere, nadezhde i lyubvi [The Enchiridion or on faith, hope, and love]. Kiev: UTSIMM-PRESS. 413.

Boldyrev, N. N. (2001). Kognitivnaya semantika: Kurs lektsiy po angliyskoy filologii [Cognitive semantics: course of lectures in English Philology]. Tambov: Izd-vo Tamb. un-ta. 123.

Boyer P., Barrett J. L. (2015). Domain Specificity and Intuitive Ontology. The Handbook of Evolutionary Psychology. eds D. M. Buss, J. Wiley \& Sons. Hoboken, NJ, USA. Retrieved from http://dx.doi.org /10.1002/9780470939376.ch3.

Boyer, P, Ramble, C. (2001). Cognitive Templates for Religious Concepts: Cross-cultural Evidence for Recall of Counter-Intuitive Representations. Cognitive Science. 25. 535-564.

Boyer, P. (1994). The Naturalness of Religious Ideas: A Cognitive Theory of Religion. Berkeley: University of California Press. 315.

Boyer, P. (2000) Functional Origins of Religious Concepts: Conceptual and Strategic Selection in Evolved Minds [Malinowski Lecture 1999]. Journal of the Royal Anthropological Institute. 2000. 6. 195-214.

Bruner, Dzh. (1977). Psikhologiya poznaniya [Psychology of cognition]. M. 412.

Bugayeva, I. V. (2014). Teolingvistika: teologiya + lingvistika? [Theolinguistics: theology + linguistics? Retrieved from http://www.docplayer.ru/61738213-Teolingvistika-teologiya-lingvistika.html

Cherkhava, O. O. (2011). Anglomovne bibliyne prorotstvo yak riznovid fideïstichnogo diskursu (na materiali KING JAMES BIBLE) [Reconstruction of theolinguistic religious popular discourse matrix (based on the KING JAMES BIBLE]: avtoref. dis. ... kand. filol. nauk. Odesa: B.v. 20.

Cherneyko, L. O. (2010). Lingvofilosofskiy analiz abstraktnogo imeni [Linguophilosophical analysis of abstract name]. M. : LIBROKOM. 272.

Churchland, P. (1989). Folk Psychology and the Explanation of Human Behavior. Neurocomputational Perspective. ed. A. Churchland. Cambridge, MA: MIT Press. 111-128.

Croft W., Cruse D. A. (2004).. Cognitive Linguistics (Cambridge Textbooks in Linguistics). Cambridge University Press. 356.

Florenskiy, P. (1999). Svyashch. Soch.: v 4 t. [Collection works:” in 4 vol.]. M. : Mysl. 3(2). 621. $627-640$.

Fodor, J. (1968). The Appeal to Tacit Knowledge in Psychological Explanation. Journal of Philosophy. 65.

Gadomskiy, A. K. (2004). O lakunakh v sisteme lingvisticheskoy nauki: problema vzaimodeystviya yazyka i religii [On lacuna in a system of linguistic science: the problem of language and religion interaction]. Kultura narodov Prichernomorya. 1. 49. 164-167. 
Gonce, L. O., Upal, M. A., Slone, D. J., Tweney R. D. (2006). Role of context in the recall of counterintuitive concepts. Journal of Cognition and Culture. 6. 521-547.

Ilarion (Alfeyev), iyerom. (1996). Tainstvo very: vvedeniye v pravoslavnoye dog-maticheskoye bogosloviye [Mistery of Faith: introduction to Orthodox dogmatic theology]. M. : Izd-vo Bratstva Svyatitelya Tikhona. 288.

Johnson, C. V. M., Kelly S. W., Bishop P. (2010). Measuring the mnemonic advantage of counter-intuitive and counter-schematic concepts. Journal of Cognition and Culture. 10. 109-121.

Keil, F. C. (1979). Semantic and Conceptual Development: An Ontological Perspective. Cambridge, MA: Harvard University Press.

Korolyova A. V. (2011). Diakhronichnyi vektor doslidzhennia struktur svidomosti y myslennia [Diachronic vector of investigating the consciousness and cognition structures]. Visnyk KNLU. Seriia Filolohiia. 4. 1. 52-58.

Kubryakova, Ye. S. (1997). Kratkiy slovar kognitivnykh terminov [Concise dictionary of cognitive terms]. eds Ye. S. Kubryakova, V. Z. Demyankov, Yu. G. Pankrats, L. G. Luzina. pod obshchey red. Ye. S. Kubryakovoy. M. : Filol. f-t MGU im. M. V. Lomonosova. 245.

Lakoff, G. (1990). Women, Fire, and Dangerous Things: What Categories Reveal about the Mind. Chicago: University of Chicago Press. 614.

Lipman, O., Bogen, H. (1923). Naive Physik. Leipzig.

Lopez, A., Atran, S., Coley, J. D., Medin, D. L. et al. (1997). The tree of life: Universal and cultural features of folkbiological taxonomies and inductions. Cognitive Psychology. 32(3). 251-295.

Mamardashvili, M. K. (1997). Strela poznaniya (nabrosok estestvennoistoricheskoy gnoseologii) [Arrow of cognition: sketches of natural-historical epistemology]. M. : Shkola "Yazyki russkoy kultury". 304.

Neretina, S. S. (1994). Slovo i tekst v srednevekovoy kulture. Kontseptualizm Petra Abelyara [Word and text in medieval culture. Abelard's conceptualism]. M. : Gnozis. 216.

Neretina, S. S. (2010). Kontsept: $v 4$ t. [Concept: in 4 vol.]. M. 2. 306.

Nikitin, M. V. (2003). Osnovaniye kognitivnoy semantiki [The fundamentals of cognitive semantics]. SPb. : Iz-vo RGPU im. A. I. Gertsena. 277.

Popova, Z. D., Sternin, I. A. (2001). Ocherki po kognitivnoy lingvistike [Essays on cognitive linguistics]. Voronezh: Istoki. 191.

Popova, Z. D., Sternin, I. A. (2007). Kognitivnaya lingvistika [Cognitive linguistics]. M. : AST, Vostok-Zapad. 315.

Postovalova, V. I. (2012). Religioznyye kontsepty v teolingvisticheskom predstavlenii [Religious concepts in Orthodox Christian Worldview (A theolinguistic analysis)]. Teolingvistika. pod red. A. Gadomskogo, K. Koncharevich. Beograd: Izdatelstvo: Univerzitet u Beogradu - Pravoslavni bogoslovski fakultet. 143-152.

Postovalova, V. I. (2014). Afonskiy spor ob Imeni Bozhiyem v kontekste stanovleniya mirosozertsaniya i dukhovnoy zhizni Rossii XX-XXI vv. [The Athon dispute over the name of God in a context of establishment of worldview and spiritual life in Russia of XX-XXI c.]. Vestnik NGU.. Novosibirsk: Izd-vo NGU. 12. 2. Seriya: Lingvistika i mezhkul'turnaya kommunikatsiya. 50-65.

Rosch, E. H. (1973). Natural categories. Cognitive Psychology. 4. 328-350.

Rosch, E. H. (1978). Principles of Categorization. Cognition and Categorization. Hillsdale, N.Y. : Lawrence Erlbaum. 27-48.

Selivanova, O. O. (2008). Suchasna linhvistyka: napriamy ta problem [Contemporary linguistics: directions and problems]. Poltava: Dovkillia-K. 712.

Slone, D. J., Gonce, L., Upal, M. A., Edwards, K., Tweney R. (2007). Imagery effects on recall of counterintuitive concepts. Journal of Cognition and Culture. 7. 355-367.

Smalley, M., Scot, K. S. (2016). Knowing Him.Lulu.com. 116.

Spelke, E. (1991). Physical knowledge in infancy: Reflections on Piaget's theory. The epigenesis of mind: Essays in biology and cognition. eds S. Carey, R. Gelman, (pp.). Hillsdale. N1: Lawrence Eribaum. 133-169.

Stepanenko, V. A. (2006). Slovo / Logos / Imya - imena - kontsept - slova: sravnitel'no-tipologicheskiy analiz kontsepta "Dusha. Seele. Soul” (na materiale russkogo, nemetskogo i angliyskogo yazykov) [Word / Logos / Name - names - concept - words: comparative-typological analysis of the concept “Душа. Seele. Soul” (based on material of the Russian, German, and English languages)]: avtoref. dis. ... dokt. filol. nauk. Irkutsk. 38.

Stepanov, Yu. S. (1997). Konstanty. Slovar russkoy kultury. Opyt issledovaniya [Constants. Dictionary of Russian culture. Experience of investigation]. M. : Shkola "Yazyki russkoy kultury". 824.

Sternin, I. A. (2015). Yazyk i myshleniye: uchebno-metodicheskoye posobiye [Language and cognition: study manual]. M-Berlin : Direkt-Media. 25. 
Upal, M. A., Owsianiecki, L., Slone, D. J., Tweney, R. D. (2007). Contextualizing counterintuitiveness: How context affects comprehension and memorability of counterintuitive concepts. Cognitive Science. 31. 1-25.

Whiten, A. (1991). Natural Theories of Mind: The Evolution, Development and Simulation of Everyday Mind-reading. Oxford: Blackwell.

\section{Бібліографічний опис:}

Ізюмцева, Г. В. (2018). Реконструкція структури теоконцепту як багатовимірного утворення матричного формату. Науковий часопис Національного педагогічного університету імені М. П. Арагоманова. Серія 9 Сучасні тенденції розвитку мов. К. Вип. 17. С. 57-67. DOI: https://doi.org/10.31392/NPU-nc.series9.2018.17.05

\section{Анотація}

У статті розглянуто проблему реконструкції структури теоконцепту як смислоутворювального базового компонента релігійної картини світу. Витлумачено теоконцепт як багатовимірне утворення, яке втілюе фізичний $i$ духовний досвід людини (народу) $i$ водночас характеризусться історично зумовленою світоглядною складовою. Наведено аргументи шзодо дочільності розгляду структури концепту з позииій діахронно-синхронного підходу. Основну увагу приділено вивченню теоконцептів на тлі інших типів концептів та їх модусів, насамперед, як абстрактних онтологічно-інтуїтивних ментальних сутностей.

Здійснено реконструкцію сімох рівнів структури теоконцепту REPENTANCE, яка засвідчує, шзо це утворення має когнітивно-матричний формат. Виявлено, що ядерний зміст теоконцепту сформований значенням “tигn”, яке згідно з Біблійним контекстом відтворює сутність каяття (перший рівень). Навколоядерну зону утворюють значення “confession”, “sacrament”, “penance”, "reconciliation”, “testament”, “reunion”, когнітивними контекстами яких є основи Православного вчення (другий рівень). Етнічна забарвленість значень конщепту виявляється через розкриття духовного смислу теоконцепту REPENTANCE “congregational confession” (mpетій рівень). Образ каяття як "the second baptism” виникає на тлі християнських символічних значень (четвертий рівень). Периферійну зону кончепту становить смисловий відтінок значення "tо tитп ажау” (“військова команда”), що розвинулося як результат народно-етимологічного його осмислення (n'ятий рівень). У контексті чернечого руху (шостий рівень) актуалізуються смислові відтінки значень "аtопетепt”, “asceticism”, “hermitage”, “anchorite”. Останній рівень (далеку зону) охоплює індивідуально-смислові, особистісні відтінки досліджуваного теоконцепту, наявні в ідіолектах вірян.

Установлено, що реконструйовані смислові рівні - це $і$ є когнітивні контексти інтерпретації ядерного значення теоконцепту REPENTANCE, які висвічують інші його смисли, щзо взаємодіють між собою й утворюють його смислову поліаспектність і багатовимірність, тобто матриию.

Ключові слова: теолінгвістика, теокончепт REPENTANCE, реконструкція, когнітивна матричя, польова модель теокониепту. 